\title{
A Taxonomic Study of Some Coryneform Bacteria
}

\author{
By I. J. BOUSFIELD \\ National Collection of Industrial Bacteria, \\ Torry Research Station, Aberdeen \\ (Accepted for publication 14 February 1972)
}

\begin{abstract}
SUMMARY
Numerical analysis has been carried out on Iro features of 158 named and unnamed coryneform bacteria. At the $30 \% \mathrm{~S}$-level, four phena of unequal size were formed, the largest of which (phenon II) was divided into two subphena at the $45 \%$ S-level representing the genera Arthrobacter and Nocardia. Phenon III was divided into two subphena at the $45 \% \mathrm{~S}$-level (IIIA and IIIB). Subphenon IIIA was made up largely of Gram-positive strains received as Flavobacterium. Subphenon IIIB contained a variety of strains including a group of cellulomonas-like organisms. Phenon IV was divided into two subphena at the $35 \%$ S-level representing the animal-pathogenic corynebacteria and Microbacterium flavum respectively. Phenon V contained six strains of which five were plant pathogenic corynebacteria. DNA base composition determinations were carried out on representative strains and the values obtained generally correlated well with the numerical groupings. Considerable reorganization of most coryneform genera was considered necessary and suggestions for the reclassification of species and of particular strains have been made.
\end{abstract}

\section{INTRODUCTION}

The taxonomic difficulties associated with the group of coryneform bacteria have been reviewed by Clark (1952), Jensen (1952, 1953, 1966), Gibson (1953), Bousfield (1969) and Veldkamp (1970). The coryneform group, which is characterized mainly on a morphological basis, is considered to include the genera Corynebacterium, Arthrobacter, Brevibacterium, Microbacterium, Cellulomonas, Listeria, Erysipelothrix, Mycobacterium and certain species of Nocardia, but the equivocal definition of most of these genera causes difficulties in identification.

In recent years, studies of the taxonomy of coryneform bacteria by numerical methods have included those of Da Silva \& Holt (1965), Chatelain \& Second (I966), Harrington (1966), Mullakhanbhai \& Bhat (1967), Splitstoesser, Wexler, White \& Colwell (1967), Davis, Fomin, Wilson \& Newton (1969), Davis \& Newton (1969), Masuo \& Nakagawa (1969) and Skyring \& Quadling (1970). Non-numerical studies have included those of Keddie, Leask \& Grainger (1966), Robinson (I966a,b, c, d), Abe, Takayama \& Kinoshita (1967), Komagata, Yamada \& Ogawa (1969) and Yamada \& Komagata (I970a, b). At the time that the present work was carried out only the reports of Bouisset, Breuillard \& Michel (1963) and Abe et al. (1967) were available on the DNA base composition of coryneform bacteria. Recently, Skyring \& Quadling (1970) and Yamada \& Komagata (I968, I970b) have added further information. The present account combines a numerical analysis of a range of properties of coryneform bacteria with the determination of the DNA base composition of representative strains. 


\section{METHODS}

Strains examined. A hundred and fifty-eight strains were subjected to numerical analysis, including representatives of the genera Corynebacterium, Arthrobacter, Brevibacterium, Mycobacterium, Microbacterium, Cellulomonas, Nocardia, Listeria and Erysipelothrix. In addition, several Gram-positive and Gram-variable organisms deposited with the National Collection of Marine Bacteria as species of Flavobacterium were included. Thirty-six new isolates from sea water, fish and soil were also included. Twelve original isolates from soil, cheese and activated sludge and four from surfaces of plants were kindly supplied by Professor E. G. Mulder of Wageningen, Holland, and by Dr A. M. Paton of the University of Aberdeen respectively. The strains used in this study are listed in Table I. Those obtained from culture collections have the names and catalogue numbers they bore when received. Those from other sources have the code numbers they carried at the time of receipt. New isolates are indicated by code numbers assigned to them by the author at the time of isolation.

Maintenance of strains. All strains were stored as freeze-dried cultures. Active cultures were maintained on nutrient agar (Oxoid CM 55, Oxoid Ltd, London, S.E. I) with the exceptions of the animal and plant pathogens, which were maintained on blood agar slopes and slopes of nutrient agar containing I $\%(\mathrm{w} / \mathrm{v})$ glucose respectively.

Numerical analysis. Unless otherwise stated the Oxoid nutrient media $\mathrm{CM}_{55}$ (solid) and CM67 (liquid) were used as the nutrient bases for all tests. Horse serum, $5 \%$ (v/v) (Burroughs Wellcome, Beckenham, Kent), was added for the animal pathogens. The latter organisms were incubated at $37^{\circ} \mathrm{C}$ for 7 days and all other strains were incubated at $25^{\circ} \mathrm{C}$ for I 4 days unless indicated otherwise.

Voges-Proskauer and methyl red tests, $\mathrm{H}_{2} \mathrm{~S}$ production from peptone (paper-strip method), acid-fast stain (Ziehl-Neelsen method using 3\% (v/v) $\mathrm{HCl}$ in ethanol), indole production ( $\mathrm{\%} \%, \mathrm{w} / \mathrm{v}$, tryptone water; detection by Ehrlich's reagent), liquefaction of gelatin, hydrolysis of starch (plate method), reduction of nitrate, catalase reaction and reactions in litmus milk were tested according to the Manual of Microbiological Methods (Society of American Bacteriologists, 1957). Skim milk I \% (w/v) (Difco Laboratories U.K. Division, East Molesey, Surrey), was incorporated into plates of basal medium to test for casein digestion and plates were examined under u.v. light for the production of diffusible, fluorescent pigments. The oxidase reaction was carried out by the method of Kovacs (1956). Heat resistance was tested by the method of Abd-el-Malek \& Gibson (1952). Salt tolerance was tested by incubating strains on plates of basal medium to which $2.5 \%, 5 \%, 7.5 \%$ and $10 \%$ (w/v) $\mathrm{NaCl}$ respectively had been added. Growth on plates at $0.6^{\circ} \mathrm{C}$ and $10^{\circ} \mathrm{C}$ was recorded after 3 weeks of incubation and growth at $20^{\circ} \mathrm{C}, 25^{\circ} \mathrm{C}, 30^{\circ} \mathrm{C}$ and $37^{\circ} \mathrm{Cafter} 5$ days of incubation.

High-potency 'Sentest' discs (Evans Medical Ltd, Speke, Liverpool) were used to test penicillin sensitivity. Discs were placed on plates seeded with $\mathrm{I} \mathrm{ml}$ of $24 \mathrm{~h}$ broth culture and zones of inhibition were looked for daily up to I week. Phosphatase activity was tested by the addition of $0.5 \%(\mathrm{w} / \mathrm{v})$ phenolphthalein diphosphate to plates of basal medium, which were then exposed after incubation to ammonia fumes. Cellulose digestion was tested by the addition of a filter-paper strip to the (liquid) basal medium. Incubation was continued up to 6 weeks. The anaerobic utilization of glucose ('fermentation') was tested by incubating under hydrogen in liquid medium containing $\mathrm{r} \%(\mathrm{w} / \mathrm{v})$ glucose.

Acid production was tested in $\mathrm{I} \%(\mathrm{w} / \mathrm{v})$ peptone water containing $\mathrm{I} \%(\mathrm{v} / \mathrm{v})$ Andrade's indicator and $\mathrm{r} \%(\mathrm{w} / \mathrm{v})$ of the following carbohydrates or sugar alcohols: adonitol, arabinose, cellobiose, dextrin, dulcitol, fructose, galactose, glucose, glycerol, inulin, inositol, maltose, mannitol, mannose, raffinose, rhamnose, ribose, salicin, sorbitol, sorbose, sucrose, 


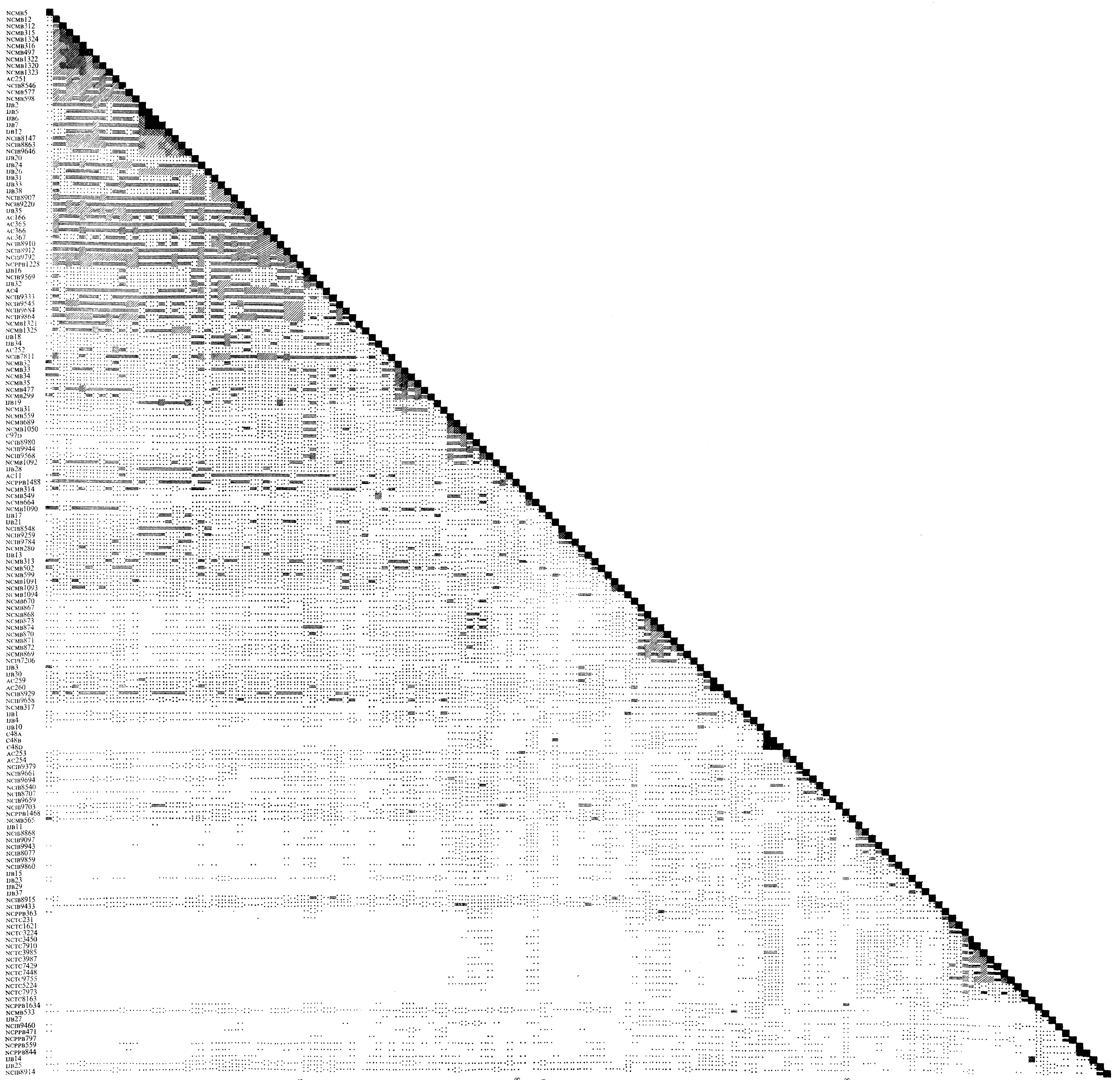

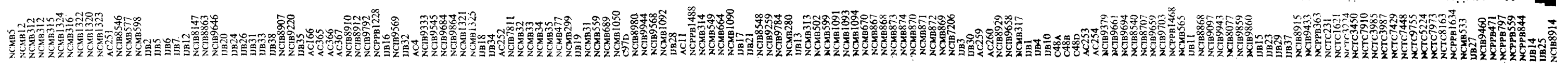
Fig. 1. Diagrammatic representation of complete S-matrix. Key to symbols $(\% \mathrm{~S}): \mathbf{D}, 90-100 ;$, 80-89; $\mathbb{N}, 70-79 ;=, 60-69:::, 50-59 ; \cdot \cdot, 40-49$. 


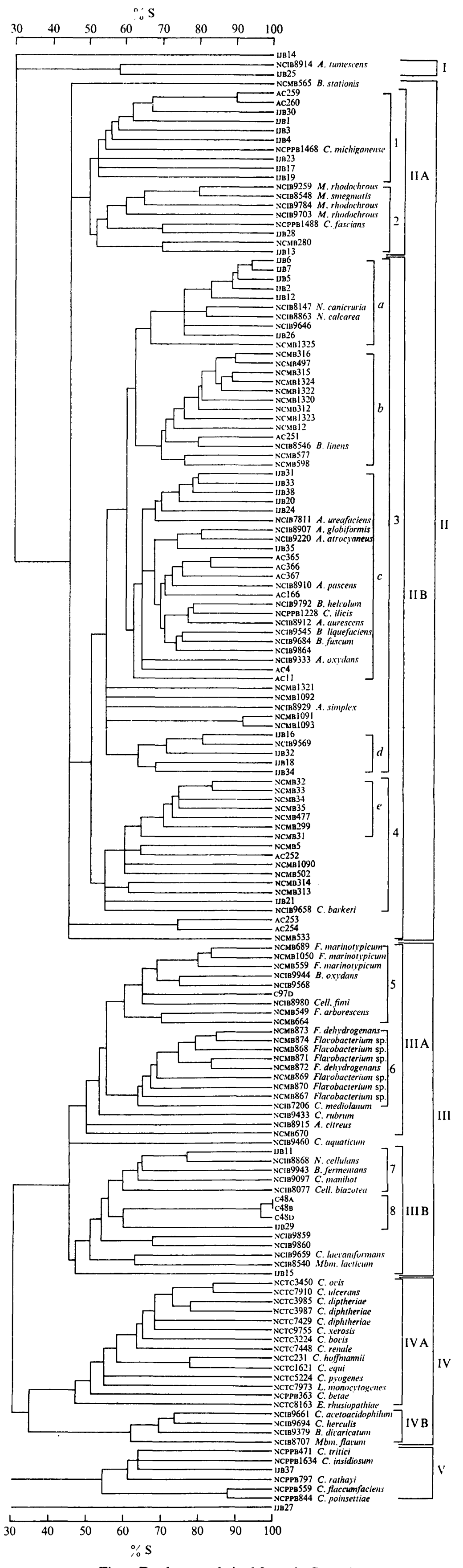

Fig. 2. Dendrogram derived from the S-matrix. 
trehalose and xylose. Hiss's serum water sugars (Wilson \& Miles, 1964) were used for the animal pathogens.

The utilization of various compounds as sole carbon sources was tested by the replicaplating method of Stanier, Palleroni \& Doudoroff (1966). The replicating device was designed and built by the Torry Research Station workshops and is fully described elsewhere (Bousfield, 1969). The basal medium used for the carbon utilization tests was that described by Stanier et al. (1966), to which was added (per 1) $2.5 \mathrm{ml}$ of the following growth factor solution (L. B. Perry, personal communication): $p$-aminobenzoic acid, $2 \mathrm{mg}$; folic acid, $2 \mathrm{mg}$; biotin, $0.4 \mathrm{mg}$; nicotinic acid, $40 \mathrm{mg}$; pantothenic acid, $40 \mathrm{mg}$; thiamin, $40 \mathrm{mg}$; $\mathrm{B}_{12}, 0.2 \mathrm{mg}$; distilled water, $100 \mathrm{ml}$. Test compounds were incorporated into the basal medium at a concentration of $0 . I \%(w / v)$ and were sterilized by filtration wherever possible, otherwise sterilization was by tyndallization. Compounds tested as sole carbon sources were the sodium salts of acetic, citric, DL-lactic, hippuric, formic, oxalic, succinic, D-malic, fumaric, malonic, meso-tartaric, pyruvic, D-mandelic and benzoic acids, phenol, glycine, L-alanine, L-serine, L-threonine, L-leucine, L-valine, L-glutamic acid, L-lysine, DL-arginine, DL-ornithine, $\gamma$-aminobutyric acid, L-histidine, L-proline, L-tyrosine, L-phenylalanine, cystine, cysteine and methionine. Plates of the basal medium described above with the addition of $1 \%(w / v)$ glucose were used to test strains for the ability to utilize inorganic nitrogen.

Computation of results. Computation of results was carried out by $\mathrm{Mr}$ J. C. Gower and Mr H. R. Simpson of the Rothamsted Experimental Station, Harpenden, Hertfordshire, using Gower's classification programme CLASP on the Orion computer. Details of this programme were kindly supplied by $\mathrm{Mr} \mathrm{H}$. R. Simpson. Negative matches were not included in the calculation of similarity. Table 2 gives the single features derived from the tests described above. In Table 2, tests marked A are 'alternatives', i.e. multistate tests in which any one of several mutually exclusive features may be recorded. Tests marked $Q$ are 'quantitatives', i.e. any point in a graduated linear series may be recorded. Tests marked D are 'dichotomies' in which the result of a particular test is either positive or negative. For any particular test, a valid comparison between two strains is made only when at least one strain has given a positive result.

Determination of DNA base composition. The isolation and purification of DNA was carried out according to the method of Marmur (196I). The guanine/cytosine ( $\%$ GC) content was determined by the thermal denaturation method of Marmur \& Doty (1962) using the saline/citrate buffer of Marmur (196I). All determinations were carried out using a Unicam SP 800 spectrophotometer (Pye/Unicam Ltd, Cambridge) fitted with a scale expansion unit and an external recorder (Bryan 'Autoplotter', Bryans Ltd, Mitcham, Surrey). Temperature was monitored by means of a plastic coated copper/constantan thermocouple inserted in the sample cuvette.

\section{RESULTS}

The complete S-matrix obtained from the numerical analysis is represented diagrammatically in Fig. I. The dendrogram derived from the S-matrix is shown in Fig. 2 and gives linkages to the $30 \% \mathrm{~S}$-level. It can be seen from the dendrogram that four phena of unequal size (phena I to IV) are formed at the $30 \% \mathrm{~S}$-level and that one further phenon (V) is formed below the $30 \% \mathrm{~S}$-level. Phenon I contains only two strains and will not be discussed further. Phenon II divides at the $45 \%$ S-level into two subphena (IIA and IIB) and three strains. Phenon III divides at the $45 \%$ S-level into two subphena (IIIA and IIIB). Phenon IV divides at the $35 \%$ S-level into two subphena (IVA and IVB). Groups within subphena 


\section{Table r. Strains used and their sources}

$\mathrm{NCIB}=$ National Collection of Industrial Bacteria $; \mathrm{NCMB}=$ National Collection of Marine Bacteria NCTC $=$ National Collection of Type Cultures; $\mathrm{NCPPB}=$ National Collection of Plant Pathogenic Bacteria; $\mathrm{AC}=$ cultures from E. G. Mulder; $\mathrm{C}=$ cultures from A. M. Paton; IJB = strains isolated_by the author.

$$
\text { Organism }
$$

\section{Corynebacterium} acetoacidophilum aquaticum barkeri

betae

bovis

diphtheriae (gravis)

diphtheriae (intermedius)

diphtheriae (PW8)

equi

erythrogenes

fascians

flaccumfaciens

herculis

hoffmannii

ilicis

insidiosum

laevaniformans

manihot

mediolanum

michiganense

ovis

poinsettiae

pyogenes

rathayi

renale

rubrum

tritici

ulcerans

xerosis

Arthrobacter
atrocyaneus
aurescens
citreus
globiformis
oxydans
pascens
simplex
tumescens
ureafaciens
sp.
sp.

Brevibacterium

divaricatum

fermentans

fuscum

helvolum

linens

liquefaciens

oxydans

stationis
Strain

NCIB966 I

NCIB9460*

NCIB9658*

NCPPB 363

NCTC3224

NCTC 3985

NCTC 3987

NCTC 7429

NCTCI $62 I^{*}$

NCMB5

NCPPBI 488

NCPPB559

NCIB9694*

NCTC23I

NCPPB 1228*

NCPPB 1634

NCIB9659*

NCIB9097*

NCIB7206

NCPPB 468

NCTC 3450

NCPPB 844

NCTC5224

NCPPB797

NCTC7448*

NCIB9433*

NCPPB47 1

NCTC7910

NCTC9755

NCIB9220*

NCIB89I2

NCIB8915

NCIB8907*

NCIB9333

NCIB89 10*

NCIB8929*

NCIB8914*

NCIB78I I

NCIB9859

NCIB9860

NCIB9379

NCIB9943*

NCIB 9684

NCIB9792

NCIB8546

NCIB9545*

NCIB9944*

NCMB565
Source

Distilled water

Sewage

Plant

Animal

Animal

Animal

Animal

Animal

Fish

Plant

Plant

Soil

Animal

Plant

Plant

Activated sludge

Cassava fermentation

Plant

Animal

Plant

Animal

Plant

Animal

Air

Plant

Animal

Animal

Air

Soil

Soil

Soil

Soil

Soil

Soil

Soil

Soil

Poultry deep litter

Poultry deep litter

Sewage

Air

Soil

Dune Sand

Cheese

Sewage

Air

Marine 
Table I (cont.)

Organism

Strain

Source

Mycobacterium

rhodochrous

rhodochrous

rhodochrous

NCIB9259

NCIB9703

smegmatis

NCIB9784

NCIB 8548

Nocardia

calcarea

cellulans

canicruria

NCIB8863*

NCIB8868

NCIB8I $47^{*}$

Microbacterium

flavum

lacticum

$\mathrm{NCIB} 8707^{*}$

NCIB8540*

Soil

Soi

Soil

Cellulomonas

biazotea

fimi

NCIB8077

NCIB8980

Listeria monocytogenes

NCTC7973

Erysipelothrix rhusiopathiae

NCTC 8163

Flavobacterium

arborescens

dehydrogenans

dehydrogenans

marinotypicum

marinotypicum

marinotypicum

sp.

sp.

sp.

sp.

sp.

sp.

'Coryneform'

NCMB549

NCMB 872

$\mathrm{NCMB} 873$

NCMB559

NCMB689

NCMB 1050

$\mathrm{NCMB} 867$

NCMB868

NCMB869

NCMB870

NCMB87 I

$\mathrm{NCMB874}$

NCIB9568

NCIB9569

NCIB9646

NCIB9864

NCMB8

NCMB 2

NCMB3I

NCMB32

NCMB33

NCMB34

NCMB 35

NCMB280

NCMB299

NCMB3I 2

NCMB3 3

NCMB3 14

NCMB3 15

NCMB3 6

NCMB3 7

NCMB477

NCMB480

NCMB497

NCMB5O2

NCMB533

NCMB577

NCMB 598

Chalk soil

Chalk soil

Soil

Cheese

Milk

Soil

Animal

Animal

Marine

Marine

Marine

Marine

Soil

Soil

Soil

Poultry deep litter

Fish

Fish

Fish

Fish

Fish

Fish

Fish

Fish

Marine

Fish

Fish

Fish

Fish

Fish

Fish

Marine

Marine

Marine

Marine

Marine

Marine

Marine 
Table I (cont.)

\begin{tabular}{|c|c|c|}
\hline Organism & Strain & Source \\
\hline 'Coryneform' (cont.) & $\begin{array}{l}\text { NCMB599 } \\
\text { NCMBIO94 } \\
\text { NCMBI } 320 \\
\text { NCMBI32 I } \\
\text { NCMBI 322 } \\
\text { NCMBI } 323 \\
\text { NCMBI 324 } \\
\text { AC4 } \\
\text { ACI I } \\
\text { ACI66 } \\
\text { AC25I } \\
\text { AC252 } \\
\text { AC253 } \\
\text { AC254 } \\
\text { AC259 } \\
\text { AC260 } \\
\text { AC365 } \\
\text { AC366 } \\
\text { AC367 } \\
\text { C48A } \\
\text { C48B } \\
\text { C48D } \\
\text { C97D } \\
\text { IJBI-IO } \\
\text { IJB I I-38 } \\
\text { pe strain. }\end{array}$ & $\begin{array}{l}\text { Marine } \\
\text { Fish } \\
\text { Marine } \\
\text { Marine } \\
\text { Marine } \\
\text { Marine } \\
\text { Marine } \\
- \\
- \\
- \\
- \\
- \\
- \\
- \\
- \\
- \\
- \\
- \\
- \\
\text { Plant } \\
\text { Plant } \\
\text { Plant } \\
\text { Plant } \\
\text { Marine } \\
\text { Soil }\end{array}$ \\
\hline
\end{tabular}

are indicated by arabic numerals on the dendrogram. For convenient description in the text, certain clusters within subphenon IIB are indicated on the dendrogram by lower case letters.

The values obtained from DNA base composition determinations are given in Table 3.

Phenon II. Most of the 92 strains in this phenon were Gram-positive, pleomorphic, coryneform rods with a morphological cycle. With the exception of NCIB9646, those strains not showing a morphological cycle under the test conditions (Mycobacterium smegmatis NCIB8548, M. rhodochrous NCIB9259, NCIB9784 and NCIB9703, IJB28, IJBI 9 and Corynebacterium fascians NCPPBI488) are all in subphenon IIA. Variations in the Gram reaction at different ages of the cultures were common, although no definite pattern emerged. In only three cases (Arthrobacter atrocyaneus NCIB9220, A. globiformis NCIB8907 and A. pascens NCIB8910) did cells appear completely Gram-negative in very young cultures, becoming Gram-positive as the cultures aged. Only three strains ( $M$. smegmatis NCIB8548, M. rhodochrous NCIB9259 and NCIB9784) were acid-fast by the method used. All strains in phenon II were strict aerobes and were able to utilize ammonium nitrogen. Most strains did not produce acid from a wide range of carbohydrates but were able to utilize acetate, pyruvate, citrate and lactate as sole carbon sources. Strains in subphenon IIA were generally feebly or nonproteolytic whereas those in subphenon IIB, with the exception of a few strains in cluster 3 , were actively proteolytic. Members of IIB also appeared to utilize more amino acid as sole carbon sources than did members of II A. With the exceptions of M. smegmatis NCIB8548 (70\% GC) and Corynebacterium michiganense NCPPB I 468 ( $7 \mathrm{I} \%$ GC) all strains tested in subphenon II A showed \% GC values in the range 6r to 66 and were indistinguishable by $\%$ GC values from strains in subphenon IIB, which showed values in the range $6 \mathrm{r}$ to $64 \%$. This phenon contains all the named strains of Nocardia, Mycobacterium and Arthrobacter with the exceptions of $A$. citreus NCIB89I5, A. tumescens NCIB89I4 and Nocardia cellulans NCIB8868. 
Table 2. Individual features recorded for numerical analysis
(D) Acid from adonitol
(D) Acid from arabinose
(D) Utilization of inorganic nitrogen
(D) Acid from cellobiose
(D) Acid from dextrin
(D) Acid from fructose
(D) Acid from galactose
(D) Acid from glucose
(D) Acid from glycerol
(D) Acid from inulin
(D) Acid from inositol
(D) Acid from lactose
(D) Acid from maltose
(D) Acid from mannitol
(D) Acid from mannose
(D) Acid from raffinose
(D) Acid from rhamnose
(D) Acid from ribose
(D) Acid from salicin
(D) Acid from sorbitol
(D) Acid from sorbose
(D) Acid from sucrose
(D) Acid from trehalose
(D) Acid from xylose
(D) Utilization of acetate
(D) Utilization of citrate
(D) Utilization of lactate
(D) Utilization of hippurate
(D) Oxidase production
(D) Catalase production
(D) $\mathrm{H}_{2} \mathrm{~S}$ production
(D) Phosphatase production
(D) Casein hydrolysis
(D) Gelatin hydrolysis
(D) Starch hydrolysis
(D) Urea hydrolysis
(D) Voges-Proskauer test
(D) Methyl red test
(A) Penicillin (sensitive/resistant)
(D) Anaerobic growth in glucose
(D) $\mathrm{NO}_{3}$ reduction
(D) Litmus milk-reduction
(D) Litmus milk-acid
(D) Litmus milk-proteolysis
(D) Litmus milk-clot
(D) Cellulose decomposition
(Q) $\mathrm{NaCl}$ tolerance $(2.5 \% / 5 \% / 7.5 \% / 10 \%)$
(Q) Growth temperatures - 'high' $\left(30^{\circ} / 37^{\circ} / 45^{\circ} \mathrm{C}\right)$
(Q) Growth temperatures - 'low' $\left(0.6 \% 10^{\circ} / 20{ }^{\circ} \mathrm{C}\right)$
(D) Heat resistance
(D) Rods
(D) Cocci
(D) Cocco-bacilli
(D) Clubs
(D) 'Chinese letters'
(D) V-forms
(D) Filaments
(D) Palisades
(D) 'Cystites'
(D) 'Adderheads'
(Q) Length of rods
(Q) Thickness of rods
(D) Granules in cells
(D) Branching
(D) 'Life-cycle'
(A) Gram-stain $6 \mathrm{~h}(+1 \pm 1-)$
(A) Gram-strain $24 \mathrm{~h}(+1 \pm 1-)$
(A) Gram-strain $48 \mathrm{~h}(+/ \pm /$ - $)$
(D) Acid fastness
(D) Motility
(A) Colony surface (rough/smooth/mucoid)
(A) Colony elevation (flat/convex)
(A) Colony pigment (cream/yellow/orange/pink)
(A) Colony margin (entire/irregular)
(A) Colony opacity (translucent/opaque)
(Q) Colony size
(D) Surface ring in broth
(D) Pellicle in broth
(A) Sediment in broth (floccose/pellet)
(Q) Turbidity in broth
(D) Production of fluorescent pigment
(A) Colour of fluorescent pigment (red/green)

NB. Since all results for production of indole and production of acid from dulcitol were negative, these tests were omitted from the computation. $(\mathrm{A})=$ Alternative, $(\mathrm{D})=$ dichotomy, $(\mathrm{Q})=$ quantitative. See text for explanation. 
Table 3. $T_{\mathrm{m}}$ and $\%$ GC values of selected strains

All $\%$ GC values are given to the nearest $0.5 \%$.

\begin{tabular}{|c|c|c|c|c|}
\hline \multicolumn{2}{|l|}{$\begin{array}{l}\text { Strain } \\
\text { IJB30* }\end{array}$} & Phenon & $T_{\mathrm{m}}\left({ }^{\circ} \mathrm{C}\right)$ & $\% \mathrm{GC}$ \\
\hline \multicolumn{2}{|l|}{ IJB30* } & II & $95 \cdot 3$ & $63 \cdot 5$ \\
\hline NCMB280* & & II & $96 \cdot 4$ & 66 \\
\hline NCIB8548 & Mycobacterium smegmatis & II & $97 \cdot 9$ & 70 \\
\hline NCIB9259 & M. rhodochrous & II & $96 \cdot 4$ & 66 \\
\hline IJB $28 *$ & & II & 94.9 & $62 \cdot 5$ \\
\hline NCIB8863 & Nocardia calcarea & II & $94: 9$ & $62 \cdot 5$ \\
\hline NCIB8I 47 & N. canicruria & II & 94.6 & $6 I \cdot 5$ \\
\hline NCIB9646* & & II & $94 \cdot 8$ & 62 \\
\hline NCPPBI 488 & Corynebacterium fascians & II & $94 \cdot 2$ & $6 I$ \\
\hline NCIB 8546 & Brevibacterium linens & II & $94 \cdot 4$ & 61 \\
\hline NCMB I $324^{*}$ & & II & $94 \cdot 9$ & $62 \cdot 5$ \\
\hline NCMBI $2 *$ & & II & $95 \cdot 6$ & 64 \\
\hline NCIB 8907 & Arthrobacter globiformis & II & $95 \cdot 3$ & 63.5 \\
\hline NCIB78I I & A. ureafaciens & II & $94 \cdot 8$ & 62 \\
\hline NCIB89IO & A. pascens & II & $95 \cdot 3$ & 63.5 \\
\hline NCIB9792 & Brevibacterium helvolum & II & $94 \cdot 3$ & 61 \\
\hline NCPPBI 228 & Corynebacterium ilicis & II & $94 \cdot 6$ & $6 I \cdot 5$ \\
\hline IJB $35^{*}$ & & II & $94 \cdot 6$ & $6 I \cdot 5$ \\
\hline NCIB9545 & Brevibacterium liquefaciens & II & $94 \cdot 8$ & 62 \\
\hline NCIB9684 & B. fuscum & II & $94 \cdot 8$ & 62 \\
\hline NCMB3I* & & II & $94 \cdot 6$ & $6 I \cdot 5$ \\
\hline $\mathrm{NCMB} 35^{*}$ & & II & $94 \cdot 6$ & $6 \mathrm{I} \cdot 5$ \\
\hline NCIB9569* & & II & $94 \cdot 8$ & 62 \\
\hline NCPPBI 468 & Corynebacterium michiganense & II & $98 \cdot 5$ & $7 \mathrm{I}$ \\
\hline NCPPB 559 & C. flaccumfaciens & II & $97 \cdot 2$ & 68 \\
\hline NCPPB 844 & C. poinsettiae & II & $97 \cdot 9$ & 70 \\
\hline NCMB5 & C. erythrogenes & II & $94 \cdot 3$ & $6 \mathrm{I}$ \\
\hline NCMBI050 & Flavobacterium marinotypicum & III & $96 \cdot I$ & $65 \cdot 5$ \\
\hline NCIB9944 & Brevibacterium oxydans & III & $96 \cdot 9$ & 67 \\
\hline NCIB 8980 & Cellulomonas fimi & III & $96 \cdot 4$ & 66 \\
\hline NCMB87I & Flavobacterium $\mathrm{sp}$. & III & $96 \cdot 4$ & 66 \\
\hline NCMB 868 & Flavobacterium sp. & III & $96 \cdot 3$ & 66 \\
\hline NCIB7206 & Corynebacterium mediolanum & III & $96 \cdot 3$ & 66 \\
\hline $\mathrm{NCIB8540}$ & Microbacterium lacticum & III & $98 \cdot I$ & 70 \\
\hline $\mathrm{C} 48 \mathrm{~A}^{*}$ & & III & $93 \cdot 6$ & 59 \\
\hline NCMB670* & & III & $99 \cdot 0$ & 73 \\
\hline NCIB8077 & Cellulomonas biazotea & III & $98 \cdot 6$ & $7 I \cdot 5$ \\
\hline NCIB8868 & Nocardia cellulans & III & $98 \cdot I$ & 70 \\
\hline NCIB 9943 & Brevibacterium fermentans & III & $99 \cdot I$ & 73 \\
\hline NCIB9097 & Corynebacterium manihot & III & $98 \cdot I$ & 70 \\
\hline NCIB9 $859^{*}$ & & III & $96 \cdot 3$ & 66 \\
\hline NCIB9860* & & III & $96 \cdot 4$ & 66 \\
\hline NCTC7429 & Corynebacterium diphtheriae & IV & $92 \cdot 3$ & 55 \\
\hline NCTC9755 & C. xerosis & IV & 93.6 & 59 \\
\hline NCPPB363 & C. betae & IV & $96 \cdot 5$ & $66 \cdot 5$ \\
\hline NCIB9379 & Brevibacterium divaricatum & IV & $90 \cdot 2$ & $5 I$ \\
\hline NCIB9694 & Corynebacterium herculis & IV & $90 \cdot 3$ & $2 \mathrm{I}$ \\
\hline NCIB966I & C. acetoacidophilum & IV & $90 \cdot 3$ & $5 \mathrm{I}$ \\
\hline $\mathrm{NCIB} 8707$ & Microbacterium flavum & IV & $92 \cdot 8$ & 56 \\
\hline
\end{tabular}

* These strains have not been formally identified and are therefore not given names.

Phenon III. Most of the 36 strains in this phenon were slender, Gram-positive or Gramvariable coryneform rods (and occasionally filaments) breaking down into cocco bacilli in 48 to $72 \mathrm{~h}$. Individual cells were generally smaller than those found in strains of phenon II and they stained less deeply by the Gram-reaction. No strains were acid-fast by the method used. Motility was quite often encountered in this phenon, but no pattern was apparent. 
All strains in subphenon IIIA were strict aerobes and were able to utilize ammonium nitrogen. Most strains produced acid from a fairly wide range of carbohydrates and were able to utilize acetate, lactate, pyruvate and glutamate as sole carbon sources. All the socalled Flavobacterium strains in cluster 6 were able to withstand heating at $60^{\circ} \mathrm{C}$ for $30 \mathrm{~min}$. All strains in subphenon IIIB with the exceptions of NCIB9860 and IJBI 5 were facultatively anaerobic. Most strains readily produced acid from a wide range of carbohydrates and were able to utilize ammonium nitrogen. The ability to utilize various compounds as sole carbon sources was much less pronounced than in subphenon IIIA. Three strains (Cellulomonas biazotea NCIB8077, Nocardia cellulans NCIB8868 and IJBII) were cellulolytic. The $\% \mathrm{GC}$ values for strains tested in subphenon IIIA were in the narrow range 65 to 67 , whereas the range of $\% \mathrm{GC}$ values in subphenon IIIB was much wider. The value obtained for the single strain tested in cluster $8\left(\mathrm{C}_{4} 8 \mathrm{~A}\right)$ was $59 \%$ and that obtained for NCIB9859 and NCIB9860 was $66 \%$. The \% GC values for all other strains tested in this subphenon $(C$. biazotea NCIB8077, N. cellulans NCIB8868, Brevibacterium fermentans NCIB9943, Corynebacterium manihot NCIB9097, Microbacterium lacticum NCIB8540 and NCMB670) were in the range 70 to $73 \%$.

Phenon $I V$. Most strains in this phenon were Gram-positive or Gram-variable coryneform rods of various sizes. With the exception of Corynebacterium ovis NCTC3450 and Brevibacterium divaricatum $\mathrm{NCIB9379}$ a morphological cycle was not noted. Listeria monocytogenes NCTC7973 and Erysipelothrix rhusiopathiae NCTC8163 were morphologically exceptional in that neither strain showed any of the usual coryneform features. The former showed straight, regular rods whilst the latter showed loops, 'horseshoes' and filaments. Neither of these strains showed any morphological similarity to any other strain included in the present study. All strains with the exception of C. betae NCPPB363 were facultatively anaerobic. Strains in subphenon IVB utilized ammonium nitrogen under the test conditions, whereas those in subphenon IV A did not. All strains in subphenon IV B with the exception of Microbacterium flavum NCIB8707 were able to tolerate heating at $63^{\circ} \mathrm{C}$ for $30 \mathrm{~min}$ by the method of testing. The strains in subphenon IVA tested for DNA base composition ( $C$. betae NCPPB 363 , C. diphtheriae NCTC7429 and C. xerosis NCTC9755) had \% GC values of $66 \cdot 5,55$ and 59 respectively. The \% GC value for M. flavum NCIB8707 was 56; that for the other three strains in subphenon IVB was $5 \mathrm{I}$.

Phenon $V$. The six strains in this small phenon were Gram-positive or Gram-variable, pleomorphic, coryneform rods. No morphological cycle was observed in any of the strains in this phenon. All strains were strictly aerobic and were able to utilize ammonium nitrogen. Most of the sugar fermentation and carbon utilization tests gave negative results.

\section{DISCUSSION}

In general, our results are in agreement with those obtained in similar studies by other workers which have also indicated that some redistribution of strains in the various coryneform genera appears necessary. To this end, each major phenon will be discussed in turn and its status in the context of current coryneform genera will be considered.

Phenon II. This phenon represents Nocardia/Mycobacterium and Arthrobacter. Most strains in II A were similar to the Mycobacterium rhodochrous group of organisms described by Gordon (1966). None of the strains in IIA appeared to be closely related to the animal pathogenic corynebacteria of phenon IV, which supports the conclusion of Davis \& Newton (1969) that despite earlier suggestions to the contrary (Cummins 1962; Harrington, I966), Mycobacterium and Nocardia should remain separate from Corynebacterium. 
The inclusion of Corynebacterium fascians in IIA supports the already considerable body of evidence that this organism is a nocardia (Lacey, 1955; Ramamurthi, 1959) or at least a member of the Mycobacterium rhodochrous group (Gordon (I966), who discussed the difficulties of assigning the latter group to a suitable genus).

Corynebacterium michiganense NCPPBI 468 is placed in subphenon IIA, whereas Da Silva \& Holt (1965) and Davis \& Newton (1969) found that the strains of C. michiganense used by them clustered with Microbacterium lacticum. The single strain of M. lacticum (NCIB8540) used in the present work is placed (unclustered) in subphenon IIIB.

All strains in IIB showed the morphological 'life-cycle' of 'typical' arthrobacters. This phenomenon appears to be the principal feature of the genus Arthrobacter as originally defined by Conn \& Dimmick (I947), and Skerman (1967) emphasizes that, in the identification of Arthrobacter, the final transformation into cocci is the most important feature to be observed. Bergey's Manual of Determinative Bacteriology (Breed, Murray \& Smith, I957) also stresses this point. Whilst such a morphological cycle may be a prerequisite for the genus Arthrobacter, our results show that it is by no means restricted to this genus. Indeed, its occurrence in the coryneform group seems to be the rule rather than the exception (Veldkamp, 1970) and it has been observed in many coryneform organisms including Cellulomonas and Corynebacterium diphtheriae, albeit less strikingly than in 'typical' arthrobacters (Ørskov, 1923; Grubb \& Koser, I934; Jensen, 1952; Gibson, 1953; Müller, I957; Kuhn \& Starr, 1962; Mulder \& Antheunisse, 1963). Keddie et al. (I966) commented upon the unreliability of the 'life-cycle' as a definitive criterion for the recognition of Arthrobacter species, concluding that the creation of a separate genus on morphological grounds alone was not justified. Thus Arthrobacter must be defined by more suitable criteria than the mere occurrence of a morphological cycle. In this context, the study of nutritional features and cell-wall composition may prove useful in the future (Keddie, Leask \& Grainger, I966; Owens \& Keddie, I968, 1969; I. J. Bousfield, unpublished results).

In subphenon IIB, cluster c appears to represent the Arthrobacter globiformis type of coryneform. Included in cluster c are Brevibacterium helvolum $\mathrm{NCIB9792,} \mathrm{B.} \mathrm{liquefaciens}$ NCIB9545, B. fuscum NCIB9684 and Corynebacterium ilicis NCPPBI228, all of which are very similar to A. globiformis and all of which would be more suitably accommodated in the genus Arthrobacter than in either of Brevibacterium or Corynebacterium. Cluster b consists of Brevibacterium linens NCIB8546 and similar strains. The similarity of $B$. linens to members of Arthrobacter has already been noted by several workers (e.g. Schefferle, 1957; Mulder \& Antheunisse, 1963; Mulder, 1964; Mulder et al. 1966) and Da Silva \& Holt (1965) and Davis \& Newton (1969) suggested that it be renamed Arthrobacter linens. If the results of previous work are taken with those obtained in the present study, it would seem that $B$. linens, whilst differing in several respects from A. globiformis, should nevertheless be contained in the same genus as the latter.

The inclusion of cluster a in subphenon IIB is of note since this cluster includes named strains of Nocardia canicruria and N. calcarea, organisms considered by Gordon (I966) to belong to the Mycobaterium rhodochrous group. The strains in cluster a are, in fact, linked to many of the strains in subphenon IIA as can be seen from the S-matrix in Fig. I. These linkages cannot be satisfactorily indicated on the dendrogram in Fig. 2. However, the various linkages shown by the strains of cluster a tend to emphasize the indeterminate nature of the boundary between Arthrobacter and Nocardia.

Cluster $\mathbf{d}$ consists of unnamed arthrobacter-like soil strains and cluster e consists of unnamed marine organisms linked to a further four marine strains including Corynebacterium erythrogenes NCMB5, which again would seem to be more suitably placed in Arthrobacter 
than in Corynebacterium. Corynebacterium barkeri NCIB9658, which is amongst the unclustered strains in subphenon IIB, also seems to resemble the arthrobacters more than the corynebacteria.

Phenon III. Most of the strains in subphenon III A were originally designated Flavobacterium strains, but it seems obvious that these so-called flavobacteria are coryneforms. The similarity of the Flavobacterium strains of group 6 to Corynebacterium mediolanum NCIB7206 is enhanced by their cell wall composition (Bousfield, I969). The cell walls of all the strains in group 6 contain diaminobutyric acid as the principal diamino acid. This compound was previously reported in the cell wall of Corynebacterium tritici (Perkins \& Cummins, 1964).

The strains in subphenon IIIA could be regarded as all belonging to the same genus, since in addition to their overall similarity the $\% \mathrm{GC}$ range is fairly narrow (65 to 67), but selection of a suitable genus remains a problem. These strains were sufficiently distinct in this study to warrant their exclusion from all of the existing coryneform genera. The only previously described genus into which the strains of subphenon IIIA can be easily fitted is Brevibacterium (Chatelain \& Second, 1966). One of the strains of Chatelain \& Second (Brevibacterium oxydans NCIB9944) is included in subphenon IIIA. However, Brevibacterium (Chatelain \& Second, 1966) is illegitimate as it does not include $B$. linens, the type species of the genus Brevibacterium (Breed, $1953 a, b$ ) which was legitimately described. Therefore, the creation of a new genus would seem to be needed.

Included in subphenon IIIA is a strain of Cellulomonas fimi (NCIB8980), an organism which seems to be wrongly classified since it is non-cellulolytic and shows very little relationship with Cellulomonas biazotea. Also included in subphenon III A is Corynebacterium rubrum NCIB9433, which according to Gordon (1966) is similar to Mycobacterium rhodochrous, but this similarity has not been demonstrated in the present work.

In subphenon IIIB the strains of group 7 (Nocardia cellulans NCIB8868, Brevibacterium fermentans NCIB9943, IJBI I, Corynebacterium manihot NCIB9097 and Cellulomonas biazotea NCIB8077) have a similar DNA base composition and they appear to be related in terms of overall similarity. In addition, Nocardia cellulans and IJB I I are cellulolytic. It seems possible that these strains could all belong to the same genus. However, M. Goodfellow (personal communication) found that Nocardia cellulans showed some similarity to Oerskovia turbata (Prauser, Lechevalier \& Lechevalier, 1970), the relationship of which to Nocardia cellulans and other organisms is currently under investigation in this laboratory.

Phenon IV. With the exception of three strains (Corynebacterium betae NCPPB363, Listeria monocytogenes NCTC7973 and Erysipelothrix rhusiopathiae NCTC8I63) subphenon IV A consists of animal pathogenic corynebacteria. These organisms have generally been considered closely related to each other and the present results bear this out. The $\% \mathrm{GC}$ values obtained for two strains (Corynebacterium diphtheriae NCTC7429, 54\% and C. xerosis 59\% NCTC7755) are fairly close and fall into the $\% \mathrm{GC}$ range for corynebacteria determined by Bouisset et al. (1963). However, coryneform DNA base analysis by Yamada \& Komagata (I970 $b$ ) casts some doubt both on the results of Bouisset et al. (1963) and on the apparently close interrelationships amongst the animal pathogenic corynebacteria. Yamada \& Komagata (I970 $b$ ) gave a $\% \mathrm{GC}$ range of 52 to 68 for the animal pathogenic corynebacteria, whereas the range given by Bouisset et al. (1963) was 52 to 59 .

It may be noted that Corynebacterium equi NCTCI62I falls into phenon IV and that a relationship between this organism and the mycobacteria (Jensen, 1934, 1952; Harrington, 1966) has not been demonstrated here. Although Erysipelothrix rhusiopathiae NCTC8I36 and Listeria monocytogenes NCTC7973 are included in phenon IV, their relationships with 
the coryneform bacteria appears doubtful. Neither organism shows coryneform morphology and the \% GC value for L. monocytogenes (38\%; Marmur \& Doty, 1962) is well outside the coryneform range. It has been suggested that Listeria and Erysipelothrix are more closely related to the family Lactobacillaceae than to the family Corynebacteriaceae (Davis et al. I969).

The four organisms in subphenon IVB (Microbacterium flavum NCIB8707, Corynebacterium herculis NCIB9694, C. acetoacidophilum NCIB966I and Brevibacterium divaricatum NCIB9379) are very similar to each other and in the similarity matrix appear to be linked to the strains of group 7 in subphenon IIIB. Previous reports (e.g. Robinson, I966a) indicate that $M$. flavum should belong to the same genus as the animal pathogenic corynebacteria and the $\%$ GC values for strains in subphenon IVB ( $5 \mathrm{I}$ to $56 \%$ ) are fairly close to that of Corynebacterium diphtheriae ( 52 to $54 \%$ ). Whilst these organisms are in the same phenon a close relationship has not been demonstrated here.

Phenon $V$. With the exception of IJB37, the strains in this phenon are plant-pathogenic Corynebacterium species. Since most strains gave negative results for many of the physiological tests, it is likely that this phenon has been formed largely on the basis of morphological similarities. The plant pathogenic corynebacteria in this phenon seem to be sufficiently distinct from the 'true' corynebacteria of phenon IV to warrant their exclusion from the genus Corynebacterium but they do not fit readily into any other genus.

\section{General conclusions}

The main points brought out in the present work may be summarized as follows.

(I) The genus Corynebacterium is obviously unsatisfactory as it stands at present. Whilst the animal pathogens may form a satisfactory group, other named Corynebacterium spp. are widely divergent. There may well be a case for restricting the genus Corynebacterium to certain animal pathogens and related types and for placing all other members of the genus elsewhere.

(2) The taxonomy of Brevibacterium is not satisfactory. From its inception (Breed, I953 $a, b)$, Brevibacterium was never more than a repository for a variety of Gram-positive organisms and as a defined genus it seems to have little value. The type species (Brevibacterium linens) is probably better placed in the genus Arthrobacter, thus rendering Brevibacterium invalid on nomenclatural grounds alone. A new concept of Brevibacterium was described illegitimately by Chatelain \& Second (1966) and the present work supports (in some measure) the contention of these workers that such a group of coryneforms exists and may well merit generic status. However, nomenclatural rules preclude the use of the name Brevibacterium for this group.

(3) Several organisms which were previously classified as flavobacteria would seem to be better placed in the coryneform group. These strains form the nucleus of the group mentioned in (2) above.

(4) Certain non-cellulolytic strains appear to be similar to Cellulomonas biazotea and could possibly be included in the same genus. Nocardia cellulans would also probably be better placed in Cellulomonas than in Nocardia.

(5) The genus Arthrobacter seems to be more homogeneous than many other coryneform genera and forms an admirable repository for many of the saprophytic diphtheroids and for certain aberrant strains from other coryneform genera. However, the boundary between Arthrobacter and Nocardia is ill-defined and several organisms of the Mycobacterium rhodochrous type seem to be transitional between the two genera. 
(6) The unsatisfactory nature of the genus Microbacterium has again been shown but the results have not provided a solution.

The author wishes to acknowledge the receipt of a Natural Environment Research Council grant during the course of this work. This paper was prepared as part of the programme of the Torry Research Station.

\section{REFERENCES}

Abe, S., Takayama, K. \& Kinoshita, S. (1967). Taxonomical studies on glutamic acid-producing bacteria. Journal of General and Applied Microbiology 13, 279-30I.

AbD-el-MaleK, Y. \& GibSon, T. (I952). Studies in the bacteriology of milk. III. The corynebacteria of milk. Journal of Dairy Research 19, I53-159.

Bouisset, L., Breulllard, J. \& Michel, G. (I963). Étude de l'ADN chez les Actinomycetales. Annales de l'Institut Pasteur 104, 756-770.

Bousfield, I. J. (1969). A Taxonomic Study of Some Aerobic Coryneform Bacteria. PhD Thesis, University of Aberdeen.

BREED, R. S. $(1953 a)$. The Brevibacteriaceae fam.nov. of order Eubacteriales. Abstracts of Communications, 6th International Congress of Microbiology, Rome 1, 13-I4.

BReED, R. S. (1953b). The families developed from Bacteriaceae Cohn with a description of the family Brevibacteriaceae Breed 1953. Proceedings of 6th International Congress of Microbiology, Rome 1, IO-I5.

Breed, R. S., Murray, E. G. D. \& Smith, N. R. (1957). Bergey's Manual of Determinative Bacteriology, 7 th edn. London: Baillère, Tindall \& Cox.

Chatelain, R. \& Second, L. (I966). Taxonomie numérique de quelques Brevibacterium. Annales de l'Institut Pasteur III, 630-644.

CLARK, F. E. (1952). The generic classification of the soil corynebacteria. International Bulletin of Bacterial Nomenclature and Taxonomy 2, 45-56.

Conn, H. J. \& Dimmick, I. (1947). Soil bacteria similar in morphology to Mycobacterium and Corynebacterium. Journal of Bacteriology 54, $29 \mathrm{I}-303$.

Cummins, C. S. (1962). Immunochemical specificity and the location of antigens in the bacterial cell wall. In Microbial Classification, Symposium of the Society for General Microbiology I2, 21 2-24I.

DA Silva, G. A. N. \& Holt, J. G. (1965). Numerical taxonomy of certain coryneform bacteria. Journal of Bacteriology 90, 92 I-927.

Davis, G. H. G., Fomin, L., Wilson, E. \& Newton, K. G. (1969). Numerical taxonomy of Listeria, streptococci and possibly related bacteria. Journal of General Microbiology 57, 333-348.

DAVIs, G. H. G. \& NewTON, K. G. (1969). Numerical taxonomy of some named coryneform bacteria. Journal of General Microbiology 56, 195-214.

Gibson, T. (1953). The taxonomy of the genus Corynebacterium. Proceedings of 6th International Congress of Microbiology, Rome I, I6-20.

Gordon, R. E. (r966). Some strains in search of a genus-Corynebacterium, Mycobacterium or what? Journal of General Microbiology 43, 329-343.

GrubB, T. C. \& Koser, S. A. (1934). Coccus forms of Corynebacterium diphtheriae. Journal of Bacteriology $27,45$.

HARRINGTON, B. J. (I966). A numerical taxonomical study of some corynebacteria and related organisms. Journal of General Microbiology 45, 3I-40.

JENSEN, H. L. (1934). Studies on the saprophytic mycobacteria and corynebacteria. Proceedings of the Linnean Society of New South Wales 59, 19-6r.

JENSEN, H. L. (1952). The coryneform bacteria. Annual Review of Microbiology 6, 77-90.

Jensen, H. L. (1953). The genus Nocardia (or Proactinomyces) and its separation from other Actinomycetales, with some reflections on the phylogeny of the actinomycetes. 6th International Congress of Microbiology, Rome I, 69-88.

JENSEN, H. L. (1966). Some introductory remarks on the coryneform bacteria. Journal of Applied Bacteriology 29, $13-16$.

KEDDIE, R. M., LeAsK, B. G. S. \& GRAINGER, J. M. (I966). A comparison of coryneform bacteria from soil and herbage: cell wall composition and nutrition. Journal of Applied Bacteriology 29, 17-43.

Komagata, K., Yamada, K. \& Ogawa, H. (1969). Taxonomic studies on coryneform bacteria. I. Division of bacterial cells. Journal of General and Applied Microbiology 15, 243-259. 
Kovacs, N. (1956). Identification of Pseudomonas pyocyanea by the oxidase reaction. Nature, London 178,703 .

KunN, D. A. \& STARR, M. P. (1962). Developmental morphology of Corynebacterium poinsettiae. Bacteriological Proceedings, 46.

LACEY, M.S. (1955). The cytology and relationships of Corynebacterium fascians. Transactions of the British Mycological Society 38, 49-58.

Marmur, J. (1961). A procedure for the isolation of deoxyribonucleic acid from micro-organisms. Journal of Molecular Biology 3, 208-2 18.

MARMUR, J. \& Doty, P. (1962). Determination of the base composition of deoxyribonucleic acid from its thermal denaturation temperature. Journal of Molecular Biology 5, 109-1 I8.

Masuo, E. \& Nakagawa, T. (1969). Numerical classification of bacteria. Part II. Computer analysis of coryneform bacteria: comparison of group-formations obtained on two different methods of scoring data. Agricultural and Biological Chemistry 33, I I24-I I33.

Mulder, E. G. (1964). Arthrobacter. In Principles and Applications in Aquatic Microbiology. Edited by H. Heukelekian \& N. Dondero. New York: John Wiley \& Sons.

Mulder, E. G., Adamse, A. D., Antheunisse, J., Deinema, M. H., Woldendorp, J. W. \& Zevenhuizen L. P. T. M. (1966). The relationship between Brevibacterium linens and bacteria of the genus Arthrobacter. Journal of Applied Bacteriology 29, 44-7I.

Mulder, E. G. \& Antheunisse, J. (1963). Morphologie, physiologie et écologie des Arthrobacter. Annales de l'Institut Pasteur ro5, 46-74.

Mullakhanbhai, M. F. \& Bhat, J. V. (1967). A numerical taxonomical study of Arthrobacter. Current Science 36, I I5-I I8.

MüLler, J. (1957). Untersuchungen zur Morphologie und Physiologie der Corynebakterien. Archiv für Mikrobiologie 27, 105-I24.

ØRskov, J. (1923). Investigations into the Morphology of the Ray Fungi. Copenhagen: Levin \& Munksgaard.

Owens, J. D. \& KEDDIE, R. M. (I968). A note on the vitamin requirements of some coryneform bacteria from soil and herbage. Journal of Applied Bacteriology 3r, 344-348.

OWENS, J. D. \& KEDDIE, R. M. (I969). The nitrogen nutrition of soil and herbage coryneform bacteria. Journal of Applied Bacteriology 32, 338-347.

Perkins, H. R. \& Cummins, C. S. (I964). Chemical structure of bacterial cell walls. Ornithine and 2-4 diaminobutyric acid as components of the cell walls of plant pathogenic corynebacteria. Nature, London 201, I 105-1107.

Prauser, H., Lechevalier, M. P. \& Lechevalier, H. (I970). Description of Oerskovia gen. n. to harbour Ørskov's motile Nocardia. Applied Microbiology r9, 534.

Ramamurthi, C.S. (I959). Comparative studies on some Gram-positive phytopathogenic bacteria and their relationship to the corynebacteria. Memorandum of Cornell University Agricultural Experimental Station, no. 366. Ithaca, New York: New York State College of Agriculture.

Robinson, K. (I966a). A Study of Coryneform Bacteria with Particular Reference to the Genus Microbacterium. Ph.D. Thesis, University of Aberdeen.

Robinson, K. (1966b). Some observations on the taxonomy of the genus Microbacterium. I. Cultural and physiological reactions and heat resistance. Journal of Applied Bacteriology 29, 607-6I 5.

Robinson, K. (1966c). Some observations on the taxonomy of the genus Microbacterium. II. Cell wall analysis, gel electrophoresis and serology. Journal of Applied Bacteriology 29, 6I6-624.

Robinson, K. (I966d). An examination of Corynebacterium species by gel electrophoresis. Journal of Applied Bacteriology 29, I79-184.

Schefferle, H. E. (1957). An Investigation of the Microbiology of Built-up Poultry Litter. Ph.D. Thesis, University of Edinburgh. Cited in Mulder et al. (1966).

Skerman, V. B. D. (I967). A Guide to the Identification of the Genera of Bacteria, 2nd edn. Baltimore: Williams \& Wilkins.

SkYRING, G. W. \& QUADLING, C. (1970). Soil bacteria: principal component analysis and guanine-cytosine contents of some arthrobacter-coryneform soil isolates and of some named cultures. Canadian Journal of Microbiology 16, 95-106.

Society of American Bacteriologists (1957). Manual of Microbiological Methods. Edited by H. J. Conn. London: McGraw Hill Book Co.

Splitstoesser, D. E., WeXler, M., White, J. \& Colwell, R. R. (I967). Numerical taxonomy of Grampositive and catalase-positive rods isolated from frozen vegetables. Applied Microbiology 15, $158-162$. 
Stanier, R. Y., Palleroni, N. J. \& Doudoroff, M. (I966). The aerobic pseudomonads: a taxonomic study. Journal of General Microbiology 43, I59-27I.

VeldKamp, H. (1970). Saprophytic coryneform bacteria. Annual Review of Microbiology 24, 209-240.

Wilson, G. S. \& Miles, A. A. (1964). Topley and Wilson's Principles of Bacteriology and Immunity, vol. I, 5th edn. London: Arnold.

Yamada, K. \& Komagata, K. (I968). Taxonomic studies on coryneform bacteria. International Conference of Culture Collections Tokyo (Abstr.), p. 23. Tokyo: University of Tokyo Press.

Yamada, K. \& Komagata, K. (I970a). Taxonomic studies on coryneform bacteria. II. Principal amino acids in the cell wall and their taxonomic significance. Journal of General and Applied Microbiology 16, I03-II3.

Yamada, K. \& Komagata, K. (1970b). Taxonomic studies on coryneform bacteria. III. DNA base composition of coryneform bacteria. Journal of General and Applied Microbiology 16, 2 I 5-224. 